\title{
Assessment of Serum lonized Calcium in the Perioperative Period in Patients Undergoing Total Thyroidectomy
}

\author{
Muqdad Fuad*(i), Ahmed Modher (i) \\ Department of Surgery, College of Medicine, University of Diyala, Baqubah, Iraq
}

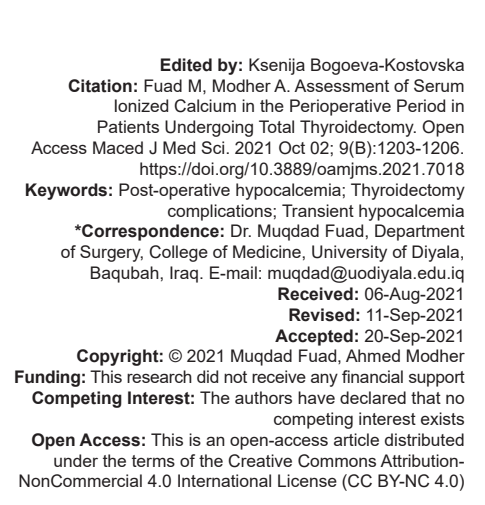

Introduction

Total or near-total thyroidectomies are among the most commonly performed surgeries worldwide. They are associated with an acceptable rate of complications, but such complications can cause patient discomfort, others are attenuating and some are seriously lethal [1]. Permanent hypocalcemia, bleeding, and vocal cord palsy are serious complications. Transient hypocalcemia is the most frequent complication encountered following both total and near-total thyroidectomies [2], [3], [4]. Hypocalcemia is the most frequent metabolic and clinical complication following major thyroidectomies. Hypocalcemia occurs in an incidence of 1.3-83\% post-thyroidectomy and it may be silent clinically if not carefully investigated [5], [6]. Abrupt and intensive decrease in the concentration of calcium in plasma seems to be the cause of occurrence of hypocalcemic symptoms despite it is still not known at which level plasma calcium provokes the appearance of hypocalcemia symptoms. It is also still a subject of debate whether being knowledgeable of this concentration level is important clinically or not [6]. Hypocalcemia following thyroidectomy mainly evolves due to many causes as unintentional removal of the parathyroid gland, parathyroid ischemia from devascularization, and damage. These induce transient or permanent state of hypoparathyroidism. Other mechanisms of developing hypocalcemia may include sudden raise in serum calcitonin levels resulted from manipulation during the operative procedure and vitamin D deficiency [7], [8]. The etiology may also involve hypocalcemia induced by alkalosis that results from hyperventilation induced by post-operative pain in addition to dilution of the already present calcium by intraoperative and post-operative fluid therapy [9]. Well knowledge of the anatomy of the parathyroid glands is the cornerstone in decreasing the incidence of hypocalcemia postoperatively [10]. Despite decreasing post-operative hypocalcemia rate because of the parathyroid preserving surgical techniques, transient hypocalcemia rate is still high ranging between 6.9 and $49 \%$ in some studies [11], [12], [13]. Investigating serum calcium levels postoperatively and specifically in the immediate day 1 and day 2 may allow identifying patients who developed hypocalcemia. The aim of the study is to evaluate the immediate post-operative sequence of serum-ionized calcium next to entire or close entire thyroidectomy to describe the incidence degree of hypocalcemia. 


\section{Method}

This is a cross-sectional study of 174 patients who underwent total and near-total thyroidectomy for any indication excluding those with proved malignancy preoperatively and those with recurrent goiter. The study attained after validation an informed agreement form according to the WHO strategies for a study concerning human focusses. The study was accomplished in Baquba Teaching Hospital/Diyala Government/Iraq. Patients excluded from the study were those who did not complete the pre-operative records of serum calcium values and those who have either hypocalcemia or hypercalcemia preoperatively. As mentioned above, patients with proved malignancy preoperatively on fine-needle aspiration cytology and those with recurrent goiter were also excluded from the study because of the high risk of unintentional parathyroid removal, devascularization, and damage in those patients. The laboratory tests needed were pre-operative and post-operative measurement of serum-ionized calcium levels on both post-operative days 1 (POD1) and 2. The laboratory tests were achieved at the Teaching Laboratories in Baquba Teaching Hospital/ Diyala Government/Iraq. A reference value of ionized calcium at 1.12-1.32 mmol/l was considered normal [14]. Statistical analysis done was by SPSS 22, frequency and percentage were used for categorical data and mean and standard deviation (SD) for continuous data. t-test was used for assessing the difference between continuous variables. $p \leq 0.05$ is considered significant. The number of approval of the ethics committee is 199 on April 25, 2020. The limitation is patient refused operation because of changes in speaking and taste and may cause restrict tongue movement during mastication.

\section{Results}

This was a cross-sectional study of 174 patients for whom total or near-total thyroidectomies were performed by the General Surgeons in Baquba Teaching

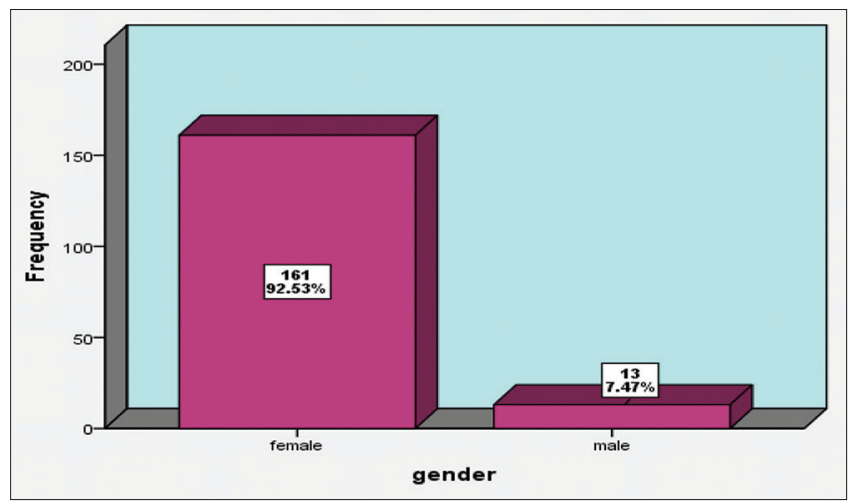

Figure 1: Gender distribution
Hospital in Diyala Government in Iraq between February 2018 and February 2021. One hundred and sixty-one $(92.53 \%)$ were females and $13(7.47 \%)$ patients were males (Figure 1). The patient's age ranged from 22 to 61 years, with a mean age of $36.3 \pm 9.4$ years. There was a significant difference between pre-operative serumionized calcium $\left(\mathrm{Ca}^{++}\right)$level and that in POD1. The mean pre-operative ionized Ca was $1.23 \pm 0.47 \mathrm{mmol} / \mathrm{l}$, while the mean mean ionized Ca on POD1 was $1.175 \pm 0.11$ $\mathrm{mmol} / \mathrm{l}$ suggesting a decrease in mean concentration of ionized $\mathrm{Ca}^{++}$in POD1 ( $p=0.0001$ ) Table 1.

Table 1: Difference between means of concentration of serumionized $\mathrm{Ca}^{++}$preoperatively and on POD1 and POD2 in $\mathrm{mmol} / \mathrm{l}$

\begin{tabular}{llll}
\hline Variables & mean $\pm \mathrm{SD}$ & $\mathrm{t}$-test & $\mathrm{p}$-value \\
\hline $\mathrm{Ca}^{++}$preoperational & $1.23 \pm 0.47$ & 6.59 & 0.0001 \\
$\mathrm{Ca}^{++} \mathrm{PO}$ day (1) & $1.175 \pm 0.11$ & & \\
$\mathrm{Ca}^{++}$preoperational & $1.23 \pm 0.47$ & 6.7 & 0.0001 \\
$\mathrm{Ca}^{++} \mathrm{PO}$ day (2) & $1.177 \pm 0.1$ & & \\
$\mathrm{Ca}^{++} \mathrm{PO}$ day (1) & $1.175 \pm 0.11$ & 0.68 & 0.5 \\
$\mathrm{Ca}^{++} \mathrm{PO}$ day (2) & $1.177 \pm 0.1$ & & \\
\hline
\end{tabular}

There was also a significant difference between preoperative serum-ionized $\mathrm{Ca}^{++}$level and that in POD2. The mean pre-operative ionized $\mathrm{Ca}$ was $1.23 \pm 0.47$ $\mathrm{mmol} / \mathrm{l}$, while the mean ionized $\mathrm{Ca}$ on POD2 was $1.177 \pm 0.1 \mathrm{mmol} / \mathrm{l}$ suggesting a decrease in the mean concentration of $\mathrm{Ca}^{++}$in POD $2(p=0.0001)$ Table 1. However, there was no significant difference between serum-ionized $\mathrm{Ca}^{++}$level in POD1 and serum-ionized $\mathrm{Ca}^{++}$level in POD2. The mean ionized Ca on POD 1 and 2 was $1.175 \pm 0.11$ and $1.177 \pm 0.1 \mathrm{mmol} / \mathrm{l}$, respectively $(p=0.5)$ Table 1. Concerning the gender, there was no significant difference in the mean concentration of serum-ionized calcium when compared preoperatively and postoperatively on both PODs 1 and 2 Table 2 .

Table 2: Difference between mean concentrations of calcium between genders preoperatively and in POD1 and POD2 in $\mathrm{mmol} / \mathrm{l}$

\begin{tabular}{lllll}
\hline Variables & Gender & Mean & Std. deviation & p-value \\
\hline Ca preoperational & Female & 1.23 & 0.05 & 0.75 \\
& Male & 1.23 & 0.05 & \\
Ca POD1 & Female & 1.17 & 0.11 & 0.57 \\
& Male & 1.19 & 0.12 & \\
Ca POD2 & Female & 1.18 & 0.1 & 0.61 \\
& Male & 1.19 & 0.11 & \\
\hline
\end{tabular}

$\mathrm{p} \leq 0.05$ (significant)

\section{Discussion}

Hypocalcemia following thyroidectomy is an important subject to be investigated since the $19^{\text {th }}$ century and yet, till today needs to be investigated more [15], [16]. Lack of agreement on a specific hypocalcaemia threshold point between studies led to a loss of comparability about how the disease occurred. Some authors separate asymptomatic hypocalcemia from hypoparathyroidism, while other researchers describe symptomatic patients as hypocalcemia [4], [17]. Some surgeons routinely prescribe calcium following total thyroidectomy. This, in turn, covers the outcomes and henceforth altering the incidence of 
symptomatic and asymptomatic hypocalcemia [18], [19]. Prescribing intravenous fluids both intraoperatively and postoperatively can cause dilution of the blood and a change in the concentration of plasma electrolytes causing a transient decline in the plasma calcium, magnesium, and phosphorus, in addition to the levels of albumin and $\mathrm{pH}$ [20]. Antidiuretic hormone is a stress hormone released as a response to trauma (surgery) causing retention of water, and this may contribute to hemodilution. Due to this hemodilution, investigating either ionized or total calcium for evaluating hypocalcemia is another confusing factor [10]. Postoperatively, the parathyroid glands increase their activity, increasing the levels of parathyroid hormones to compensate for the decline in plasma calcium [21]. About $99 \%$ of the total calcium found in the skeleton present in the form of "hydroxyapatite crystals [Ca10 (PO4) $6(\mathrm{OH}) 2$ ]". 1\% only of bone calcium is transferrable easily with the extracellular fluid below the effect of parathyroid hormone, and this helps as a quick improving mechanism for stopping an extreme decrease or increase in concentration of calcium in both the interstitial and intravascular fluids, but replacement process depends on the bone preserve of calcium [22], [23]. In the current study, we detected a significant decrease in concentration mean of ionized calcium on both POD 1 and day 2 in patients who underwent total or near-total thyroidectomy in comparison to preoperative serum-ionized calcium level. This suggests that hypocalcemia is a common event following extensive surgeries of the thyroid gland. These results are in concordance with those performed by Tolone et al. who also revealed significant hypocalcemia following extensive thyroidectomy and significant decrease in the symptoms of this hypocalcemia by routine prescription of oral calcium and vitamin $D$ supplements and heightening the likelihood of early and safe discharge from the hospital [24]. Duraru et al. in their study concluded that a reduction of $1 \mathrm{mg} / \mathrm{dL}$ calcium over $12 \mathrm{~h}$ after thyroidectomy is independently associated with risk of symptomatic hypocalcemia, and routine supplementation of post-operative calcium and vitamin $D$ significantly reduces the danger of transient hypocalcemia and its complications when compared to calcium supplements alone [22]. The level of ionized calcium on the first 2 days post thyroidectomy documents reflection of the calcium concentration when the intravascular volume changes with the prescription of intravenous fluid and this can be helpful in predicting patient going to develop hypocalcemia [25]. One significant feature definite to thyroidectomy is a contribution of the "parathyroid glands" during thyroidectomy. If all glands are affected because of damage to their vascular supply or unintentional elimination, a severe decay in parathyroid hormone levels happens, causing additional powerful hypocalcemia. Numerous surgeons have the rule of delaying the hospitalization time for screen calcium levels after operation and to inhibit patient admission to hospital again due to symptomatic hypocalcemia [26]. Jong-Lyel et al. concluded in their study that routine prescription of calcium and vitamin D orally is active in declining the occurrence and harshness of hypocalcemia following entire thyroidectomy [27].

\section{Conclusion}

A significant number of patients who undergo near-total and total thyroidectomy develop a decrease in the serum concentration of calcium postoperatively. We recommend routine supplementation of oral calcium and vitamin $\mathrm{D}$ in patients who underwent extensive thyroid surgery to prevent the symptoms related to hypocalcemia. The surgeon on follow-up visits decides the duration.

\section{References}

1. Grzegory A, Pomorski L. Perioperative calcium and Vitamin D supplementation in patients undergoing thyroidectomy literature review. Pol Przegl Chir. 2018;90(4):46-50. https://doi. org/10.5604/01.3001.0012.0975

PMid:30220675

2. Harris AS, Prades E, Tkachuk O, Zeitoun H. Better consenting for thyroidectomy: Who has an increased risk of postoperative hypocalcaemia? Eur Arch Otorhinolaryngol. 2016;273(12):443743. https://doi.org/10.1007/s00405-016-4084-4

PMid:27207140

3. Noureldine SI, Genther DJ, Lopez M, Agrawal N, Tufano RP Early predictors of hypocalcemia after total thyroidectomy: An analysis of 304 patients using a short-stay monitoring protocol. JAMA Otolaryngol Head Neck Surg. 2014;140(11):1006-13. https://doi.org/10.1001/jamaoto.2014.2435

PMid:25321339

4. Lorente-Poch L, Sancho JJ, Ruiz S, Sitges-Serra A. Importance of in situ preservation of parathyroid glands during total thyroidectomy. $\mathrm{Br} J$ Surg. 2015;102(4):359-67. https://doi. org/10.1002/bjs.9676

PMid:25605285

5. Mauriello C, Marte G, Canfora A, Napolitano S, Pezzolla A Gambardella $C$, et al. Bilateral benign multinodular goiter: What is the adequate surgical therapy? A review of literature. Int J Surg. 2016;28 Suppl 1:S7-12. https://doi.org/10.1016/j. ijsu.2015.12.041

PMid:26708850

6. De Palma M, Rosato L, Zingone F, Orlando G, Antonino A, Vitale $\mathrm{M}$, et al. Post-thyroidectomy complications. The role of the device: Bipolar vs ultrasonic device: Collection of data from 1,846 consecutive patients undergoing thyroidectomy. Am J Surg. 2016;212(1):116-21. https://doi.org/10.1016/j. amjsurg.2015.05.024

PMid:26349585

7. Sands NB, Payne RJ, Côté V, Hier MP, Black MJ, Tamilia M Female gender as a risk factor for transient post-thyroidectomy hypocalcemia. Otolaryngol Head Neck Surg. 2011;145(4):561-4. 
https://doi.org/10.1177/0194599811414511

PMid:21750342

8. Zobel MJ, Long R, Gosnell J, Sosa JA, Padilla BE. Postoperative hypoparathyroidism after total thyroidectomy in children. J Surg Res. 2020;252:63-8. https://doi.org/10.1016/j.jss.2020.02.018 PMid:32234570

9. Ozemirl A, Buldanli MZ, Yener O, Leblebici M, Eren T, Baysal H, et al. Factors affecting postoperative hypocalcemia after thyroid surgery: Importance of incidental parathyroidectomy. North Clin Istambul. 2016;3(1):9-14. https://doi.org/10.14744/ nci.2016.48802

PMid:28058379

10. Eismontas V, Slepavicius A, Janusonis V, Zeromskas P, Beisa V, Strupas $\mathrm{K}$, et al. Predictors of postoperative hypocalcemia occurring after a total thyroidectomy: Results of prospective multicenter study. BMC Surg. 2018;18(1):55. https://doi. org/10.1186/s12893-018-0387-2

PMid:30092793

11. Kakava K, Tournis S, Papadakis G, Karelas I, Stampouloglou $\mathrm{P}$, Kassi E, et al. Postsurgical hypoparathyroidism: A systematic review. In Vivo. 2016;30(3):171-80. PMid:27107072

12. Lorente-Poch L, Sancho J, Muñoz JL, Gallego-Otaegui L, Martínez-Ruiz C, Sitges-Serra A. Failure of fragmented parathyroid gland autotransplantation to prevent permanent hypoparathyroidism after total thyroidectomy. Langenbecks Arch Surg. 2017;402(2):281-7. https://doi.org/10.1007/ s00423-016-1548-3

PMid:28064342

13. Calò PG, Conzo G, Raffaelli M, Medas F, Gambardella C, DeCrea $\mathrm{C}$, et al. Total thyroidectomy alone versus ipsilateral versus bilateral prophylactic central neck dissection in clinically node-negative differentiated thyroid carcinoma. A retrospective multicenter study. Eur J Surg Oncol. 2017;43(1):126-32. https:// doi.org/10.1016/j.ejso.2016.09.017

PMid:27780677

14. Pagana KD, Pagana TJ, Pagana TN. Mosby's Diagnostic and Laboratory Test Reference. $14^{\text {th }}$ ed. St. Louis, Mo: Elsevier; 2019. Available from: https:/levolve. elsevier.com/cs/product/9780323675192?role=student. [Last accessed on 2021 May 12].

15. Filho E, Machry RV, Mesquita R, Scheffel RS, Maia AL. The timing of parathyroid hormone measurement defines the cutoff values to accurately predict postoperative hypocalcemia: A prospective study. Endocrine. 2018;61(2):224-31. https://doi. org/10.1007/s12020-018-1601-9 PMid:29721800

16. Annerbo $M$, Hultin $H$, Stålberg $P$, Hellman $P$. Left-shifted relation between calcium and parathyroid hormone in Graves' disease. J Clin Endocrinol Metab. 2014;99(2):545-51. https://doi. org/10.1210/jc.2013-2500 PMid:24248181

17. Park I, Rhu J, Woo JW, Choi JH, Kim JS, Kim JH. Preserving parathyroid gland vasculature to reduce post-thyroidectomy hypocalcemia. World J Surg 2016;40(6):1382-9. https://doi. org/10.1007/s00268-016-3423-3

\section{PMid:27028753}

18. Raffaelli M, De Crea C, D'Amato G, Moscato U, Bellantone C, Carrozza C, et al. Post-thyroidectomy hypocalcemia is related to parathyroid dysfunction even in patients with normal parathyroid hormone concentrations early after surgery. Surgery. 2016;159(1):78-84. https://doi.org/10.1016/j.surg.2015.07.038 PMid:26456131

19. Özden S, Erdoğan A, Simsek B, Saylam B, Yıldız B, Tez M Clinical course of incidental parathyroidectomy: Single center experience. Auris Nasus Larynx. 2018;45(3):574-7. https://doi. org/10.1016/j.anl.2017.07.019

PMid:28807528

20. Karamanakos SN, Markou KB, Panagopoulos K, Karavias D, Vagianos CE, Scopa CD, et al. Complications and risk factors related to the extent of surgery in thyroidectomy. Results from 2,043 procedures. Hormones (Athens, Greece). 2010;9(4):31825. https://doi.org/10.14310/horm.2002.1283

\section{PMid:21112863}

21. Maxwell AK, Shonka DC, Jr., Robinson DJ, Levine PA Association of preoperative calcium and calcitriol therapy with postoperative hypocalcemia after total thyroidectomy. JAMA Otolaryngol Head Neck Surg. 2017;143(7):679-84. https://doi. org/10.1001/jamaoto.2016.4796

\section{PMid:28418509}

22. Paduraru DN, lon D, Carsote M, Andronic O, Bolocan A. Postthyroidectomy hypocalcemia risk factors and management. Chirurgia. 2019;114:564-70. https://doi.org/10.21614/ chirurgia.114.5.564

PMid:31670631

23. Kalyoncu D, Gonullu D, Gedik ML, Er M, Kuroğlu E, İğdem AA, et al. Analysis of the factors that have effect on hypocalcemia following thyroidectomy. Ulusal Cer Derg. 2013;29:171-6. https://doi.org/10.5152/UCD.2013.2438 PMid:25931872

24. Tolone S, Roberto R, Del Genio G, et al. The impact of age and oral calcium and Vitamin D supplements on postoperative hypocalcemia after total thyroidectomy: A prospective study. BMC Surg. 2013;13(2):S11. https://doi.org/10.5152/ UCD.2013.2438

PMid:24267491

25. Riaz U, Shah SA, Zahoor I, Riaz A, Zubair M. Validity of early parathyroid hormone assay as a diagnostic tool for sub-total thyroidectomy related hypocalcaemia. J Coll Physicians Surg Pak. 2014;24(7):459-62. PMid:25052965

26. Cannizzaro MA, Lo Bianco S, Picardo MC, Provenzano D, Buffone A. How to avoid and to manage post-operative complications in thyroid surgery. Updates Surg. 2017;69(2):211 5. https://doi.org/10.1007/s13304-017-0475-3 PMid:28646422

27. Bhettani MK, Rehman M, Ahmed M, Altaf HN, Choudry UK, Khan $\mathrm{KH}$. Role of pre-operative Vitamin $\mathrm{D}$ supplementation to reduce post-thyroidectomy hypocalcemia; Cohort study. Int J Surg (London, England). 2019;71:85-90. https://doi. org/10.1016/j.ijsu.2019.08.035

PMid:31494332 